\title{
MANCHESTER
}

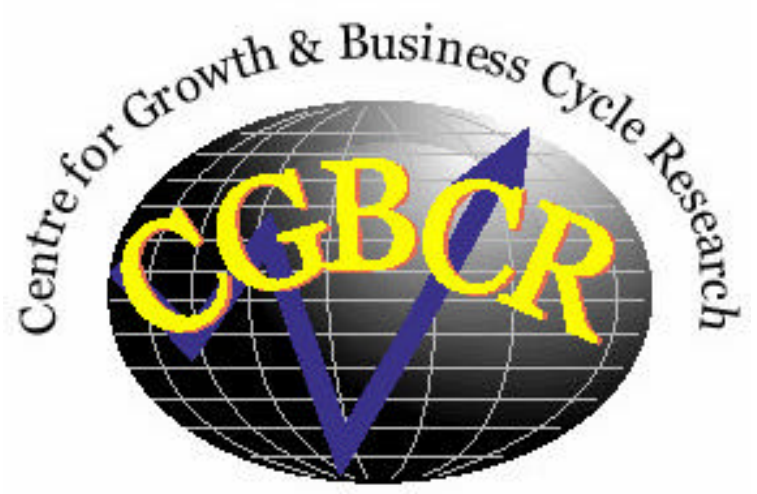

Discussion Paper Series

\section{The Optimal Public Expenditure Financing Policy: Does the Level of Economic Development Matter?} By

Niloy Bose, Jill A. Holman, and Kyriakos C. Neanidis

Centre for Growth and Business Cycle Research, Economic Studies, University of Manchester, Manchester, M13 9PL, UK

June 2005

Number 057

Download paper from:

http://www.ses.man.ac.uk/cgbcr/discussi.htm 


\title{
The Optimal Public Expenditure Financing Policy: Does the Level of Economic Development Matter?
}

\author{
Niloy Bose ${ }^{\mathrm{a}}$, Jill A. Holman ${ }^{\mathrm{a}}$, and Kyriakos C. Neanidis ${ }^{\mathrm{b}}$ \\ ${ }^{a}$ Department of Economics, University of Wisconsin-Milwaukee, Milwaukee, USA \\ ${ }^{b}$ Centre for Growth and Business Cycle Research, Economic Studies, \\ University of Manchester, Manchester, UK
}

June 2005

\begin{abstract}
This paper explores how the optimal mode of public finance depends on the stage of economic development. The theoretical analysis is based on an overlapping generations growth model with an imperfect capital market. Random shocks create a demand for liquidity and establish a role for financial intermediaries. In this model, inflation matters because it affects the relative rates of return on assets in such a way that money becomes the preferred asset in the portfolio holdings of banks, causing a detrimental effect on economic growth. Such an effect is stronger (weaker) at lower (higher) levels of economic development due to the higher (lower) default risks associated with lending. Consequently, income taxation (seigniorage) is a relatively less distortionary way of financing public expenditure for low-income (high-income) countries. We provide empirical support for our model's predictions using a panel of 21 OECD and 40 developing countries observed over the period 1972-1999.
\end{abstract}

Keywords: Public Expenditure, Public Financing, Financial Intermediaries, Economic Development, Endogenous Growth

JEL Classification: E44, E6, H6, O42

Corresponding author: Dr. Niloy Bose, Department of Economics, University of Wisconsin-Milwaukee, Bolton Hall, P.O. Box 413, Milwaukee, WI 53201, USA; Tel: +1 414229 6132; Fax: +1 414229 3860; E-mail: nbose@uwm.edu 


\section{Introduction}

Does the growth-effect of public expenditures depend on the way these expenditures are financed? Over the years, a substantial volume of theoretical and empirical research has been directed toward identifying the elements of public expenditure (at its aggregated and disaggregated level) that bear significant association with economic growth. In contrast, only a handful of studies have paid particular attention to examine the extent to which the growth-effect of public expenditures depends on the method of financing such expenditures (e.g., Miller and Russek 1997, Palivos and Yip 1995, De Gregorio 1993). The consensus appears to be that the two primary modes of financing - income taxation and seigniorage - are distortionary. Opinions, however, are divided as to their relative merits. For example, according to Palivos and Yip (1995), income tax financing is more detrimental to growth than seigniorage financing. At the same time, De Gregorio (1993) suggests that, as long as the rate of return on indexed bonds is substantially responsive to changes in the rate of inflation, seigniorage financing of public expenditure is more growth-reducing. Pecorino (1997), on the other hand, prescribes a mix of both modes of financing. Despite this, these studies share a common characteristic: the optimal mode of financing public expenditure is not contingent on the stages of economic development. Accordingly, there remains little understanding of the process by which public expenditure financing policies shape the prospect of economic growth for developing vis-à-vis developed countries. The primary objective of this paper is to bridge this gap in the existing literature.

It is a long-standing belief among development experts that outcomes of public expenditures and revenue policies are conditional on the state of an economy. Recent evidence supports such a belief. For example, Miller and Russek (1997) suggest that for developing countries, deficit-financed increases in public expenditure retard economic growth and taxfinanced increases lead to higher growth. For developed countries, deficit-financed increases in government expenditure do not affect economic growth and tax- financed increases lead to lower growth. In light of these findings and the theoretical controversy as to the relative merits of seigniorage versus tax finance, it is meaningful to ask the following question: does the relative merit of seigniorage vis-à-vis tax financing of public expenditure depend on the stages of economic development? This paper seeks an answer to this question using both theoretical and empirical analysis. 
The theoretical framework developed in this paper shares many of the characteristics of the models proposed by Schreft and Smith (1997) and Espinosa-Vega and Yip (1999, 2000). In particular, we consider a two-period overlapping-generations model where agents are subject to stochastic relocations that act like shocks to their portfolio preferences. These shocks have the same consequences as 'liquidity preference shocks' as in Diamond and Dybvig (1983) and create a role for financial intermediaries who take deposits and make a portfolio decision on behalf of the agents. In addition to these features, there is a government that relies on two alternative sources of revenue, seigniorage and income taxation, to finance its exogenously given expenditure sequence.

The result that we derive is shaped by the portfolio decision of the financial intermediaries. In particular, at each point in time, financial intermediaries are required to allocate their portfolios between a non-productive liquid asset (money) and a productive illiquid asset. The illiquid asset takes the form of financing risky investment projects, which generate productive capital stock for the economy. The financial intermediaries' optimal portfolio allocation rules depend on the relative rates of return of these two assets. An increase in inflation arising from seigniorage alters the relative rate of return of the two assets in such a way that it induces financial intermediaries to shift their portfolios in favor of liquid assets. This, in turn, has a detrimental effect on the economy's growth. Significantly, such effect is not of uniform magnitude along an economy's growth path. Our analysis suggests that this effect is larger at a low level of economic development where the rate of return on illiquid assets is low due to higher default risk associated with lending. This, in turn, makes taxation a better means of financing public expenditure for low-income countries. It is only when the capital stock exceeds a critical level, that government expenditure financed with seigniorage retards growth less than if it were financed through taxation.

The results of our theoretical analysis have direct testable implications. However, to conduct such tests it is necessary to isolate and contrast the growth effects of public expenditure when financed through taxation versus seigniorage. For this, we turn to the empirical methodology proposed by Miller and Russek (1997), Kneller et al. (1999), and Bleaney et al. (2001). These studies recognize the fact that the growth effect of public expenditure depends not only on the volume and the composition of the public spending, but also on how these expenditures are financed. Also, these studies suggest that for measuring the impact of public 
expenditure, the regression equation must include all but one possible source of finance. The omitted source of finance then becomes the implicit financing variable of public expenditure. Following this methodology, we generate results based on a data set spanning over the period 1972-1999 for 40 developing and 21 developed countries by excluding, in turn, seigniorage and tax revenue from the regression. We find strong support for our theoretical predictions in the data.

The remainder of the paper is organized as follows. In Section 2, we provide the description of the economy and derive some basic results. Section 3 analyses the balanced growth path and draws a link between the optimal mode of financing public expenditures and the stages of economic development. The results of the baseline empirical analysis and the tests for robustness are reported in the Section 4 and Section 5, respectively. Finally, section 6 concludes.

\section{Description of the Economy}

We consider an economy that consists of an infinite sequence of two-period lived overlapping generations and an initial old generation. Newly born agents are divided into three groups of market participants - households, capital-producing firms, and output-producing firms. We normalize the size of each group to 1 . All agents wish to consume only at the end of the second period. We proceed with the formal description with reference to circumstances facing each type of agent of generation $t$.

\subsection{Households}

Each household is endowed with one unit of labor when young and $0<\kappa \leq 1$ units of labor during adulthood. During both periods, labor is supplied inelastically to the market at the ruling wage rates. Households' preferences are represented by the following utility function:

$$
U\left(C_{2}\right)=-\frac{C_{2}^{-\gamma}}{\gamma},
$$

where $C_{2}$ denotes the old age consumption and $\gamma>0$. In addition, we assume that income tax is levied on the households' income at a rate $\tau$ during both periods. Since households derive utility only from the old age consumption, all first period disposable income must be saved. In the absence of any investment or storage opportunity, young households deposit their savings with the financial intermediaries. This savings, in turn, constitutes the basis of the capital formation 
for the economy. Finally, we assume that each young household faces a publicly known probability $(\pi)$ of being relocated during his old age. Realizations of these relocation shocks are identically and independently distributed across the household population. We assume that agents who relocate must liquidate all their assets and acquire cash. ${ }^{1}$ This relocation shock creates the demand for liquidity and plays an important role in the portfolio allocation of the financial intermediaries.

\subsection{Capital-producing firms (Borrowers)}

During the first period of life, firms belonging to this sector gain access to an investment project. In the absence of any form of endowment, it is necessary for these firms to acquire external funding for operating such investment project. When external funding is available, an investment project is able to convert 1 unit of time $t$ output into $x(>1)$ units of time $t+1$ capital. We assume that being an operator of an investment project, a young capital-producing firm acquires valuable experience that enables the firm to develop entrepreneurial skills to be used productively during its adulthood. In particular, we assume that each adult firm is endowed with one unit of labor which, when combined with acquired skill, produces output for its own consumption. The success of such personal endeavor, however, is not inevitable and depends on the state of the economy. When successful, an adult borrower at time period $t$ is able to obtain output that is proportional to the current market wage, $w_{t}$, and is given by $\delta w_{t}(\delta>1)$. In an event of failure, such an endeavor yields nothing.

It is well documented that the provision of public infrastructure does influence the rate of return of private investments in a positive and significant manner. However, it takes some time for such effects to materialize. At the same time, the provision of public infrastructure typically increases along the path of economic development. Keeping these stylized facts in mind, we follow Gertler and Rogoff (1989) and postulate that the probability of success, $p(\cdot)$, of the entrepreneurial endeavor by adult firms at time $t+1$ depends on the time $t$ capital stock per firm, $k_{t}$, and that $p\left(k_{t}\right)$ is increasing, strictly concave and twice continuously differentiable, with $p(0)=0$ and $p(\infty)=1$.

\footnotetext{
1 We also assume that there is limited communication across locations, which prevents agents who are relocated from trading privately issued claims. For detailed discussion, please refer to Bhattacharya et al. (1997), EspinosaVega and Yip (1999).
} 
On one hand, the above account of events implies that it is possible for individuals to transfer skills acquired in one activity to another. On the other hand, the proportionality between the wage rate and the rate of return of the entrepreneurial endeavor indicates that there may exist productivity spillovers from one sector of the economy to another. Both of these assumptions require some clarification. Transferring skills are common in practice and are often cited in literature. For example, in the 'Stepping Stone' model of Jovanovic and Nyarko (1996), agents are able to transfer skills acquired in one task to other occupations. Such activities can also be justified on the basis of empirical evidence. For example, it has been documented that firms are often able to increase the level of skills and productivity in some of their branches by transferring skills from others (e.g., Blomstrom et al. 1994).

Starting with the work of Eckstein and Wilson (1962), various attempts have been made to establish empirically the existence of wage and productivity spillovers between markets. The hypothesis under investigation is that wages in a specific sector are affected not only by market forces, but also by wage developments elsewhere. Both Brechling (1973) and Thomas and Stoney (1971), find empirical support for this hypothesis in the United States and in the United Kingdom. More recently, Drewes (1987) finds evidence of significant spillover effects in the case of Canada. In the light of new growth theory, dynamic productivity spillover effects from the core sectors to the peripheral sectors have been established as one of the important mechanisms for driving growth. This mechanism has been subjected to a large number of empirical investigations (e.g., Chuang and Lin 1999, Piazolo 1996, Van Meijl 1997) as well. These studies have put forward additional evidence in favor of sectoral spillover in an economy. Here we appeal to the foregoing empirical literature to justify the labor productivity spillover assumption in our model.

\subsection{Output-producing firms}

Output-producing firms born at time $t$ are active only during period $t+1$ when they produce output by combining capital (produced during the time period $t$ ) and labor (supplied by the young and some old households). In particular, a firm employing $k_{t+1}$ units of capital and $L_{t+1}$ units of labor produces $y_{t+1}$ units of output according to

$$
y_{t+1}=B \bar{k}_{t+1}^{\theta} k_{t+1}^{\alpha} L_{t+1}^{1-\alpha},
$$


where $\bar{k}_{t+1}$ denotes the average per firm capital stock that acts as an externality in the production of output, similar to the types of externality considered by Shell (1966) and Romer (1986). For simplicity, we assume $\theta=1-\alpha$. This allows us to reduce our model to the simplest form of endogenous growth model in which the externality effects exactly offset the diminishing marginal returns to capital in the production process (i.e., the $A k$ model). In the presence of complete factor mobility, all firms producing output must employ equal amounts of labor and capital in equilibrium. Accordingly, we obtain $\bar{k}_{t+1}=k_{t+1}$, and since there are $(1+\kappa)$ measure of labor supplied by young and old households at each time period, the labor employed by each output producing firm is given by $L_{t+1}=(1+\kappa)$. Given the above, the competitively-determined wage rate and the rental rate of capital facing each producer of output are respectively given by

$$
w_{t+1}=B(1-\alpha) k_{t+1}(1+\kappa)^{-\alpha} \equiv A(1-\alpha) k_{t+1},
$$

and

$$
r_{t+1}=B \alpha(1+\kappa)^{1-\alpha} \equiv A \alpha(1+\kappa)
$$

Finally, to reduce notational clutter, we assume that capital depreciates fully in the production of output.

\subsection{Financial Intermediaries}

As in Diamond and Dybvig (1983), we view financial intermediaries as cooperative entities consisting of coalitions formed by (young) agents. ${ }^{2}$ At each time period, financial intermediaries receive deposits from young households and make portfolio decisions about how to allocate the received funds between the two assets - lending to the capital producing firms and holding in the form of liquidity (money). As indicated earlier, a fraction $(\pi)$ of the depositors face the possibility of relocation. If such event is realized, they must liquidate all of their deposits with financial intermediaries and must acquire cash. Keeping such contingencies in mind, financial intermediaries make their optimal portfolio decisions as discussed below.

\footnotetext{
${ }^{2}$ As in Diamond and Dybvig (1983), financial intermediation arises endogenously since, unlike individual agents, the financial intermediaries are able to make a better allocation of funds by way of exploiting the law of large numbers.
} 


\subsubsection{Optimal Portfolio Decision}

In drawing up contracts with the depositors and the borrowers, financial intermediaries specify the borrowing and the lending rates together with the circumstances under which such rates are applicable. Let financial intermediaries pay individual depositors a gross real return, $R_{t}^{a}$, when they move to another location, while they pay a gross real return $R_{t}^{s}$ to those agents staying at the original location. Also, let $q$ and $(1-q)$ denote the fraction of the deposit a financial intermediary lends to the capital producing firms and holds in the form of real money balances, respectively. Finally, let $\rho_{t}$ denote the gross real lending rate that a financial intermediary charges to the capital-producing firms. To keep our exposition transparent, we consider $\rho_{t}$ as given for the time being. The determination of $\rho_{t}$ is taken up later during the analysis.

We assume that financial intermediaries operate in an environment where they compete for the depositors. In such case, any contract that yields extra economic profits to the financial intermediaries is unlikely to survive in the market because financial intermediaries would compete with each other to win the depositors by offering part or all of the extra economic profits. This amounts to saying that, in equilibrium, competition drives the financial intermediaries to do the best for the depositors. Accordingly, the financial intermediaries' portfolio problem consists of maximizing depositors' welfare by choosing a vector of deposit returns and a portfolio allocation, while satisfying a set of resource constraints. In doing so, the financial intermediaries take the gross rate of return on money holdings, $\frac{P_{t}}{P_{t+1}} \equiv R_{t}^{m}$, as given. More specifically, a financial intermediary's problem reduces to choosing $q_{t}, R_{t}^{a}$, and $R_{t}^{s}$ in order to maximize the expected utility of the depositors given by

$$
V_{t} \equiv-\pi \frac{\left[w_{t}(1-\tau) R_{t}^{a}\right]^{-\gamma}}{\gamma}-(1-\pi) \frac{\left[w_{t}(1-\tau) R_{t}^{s}\right]^{-\gamma}}{\gamma}
$$

subject to

$$
\pi R_{t}^{a}=R_{t}^{m}\left(1-q_{t}\right)
$$

and

$$
(1-\pi) R_{t}^{s}=\rho_{t} q_{t}
$$


The resource constraint in equation (6) ensures that the financial intermediaries are able to meet the liquidity needs of those depositors who are required to move to another location. Equation (7) indicates that the fraction $(1-\pi)$ of households staying in the same location must be repaid from the income generated by financial intermediaries' from lending to capital-producing firms.

The solution to the financial intermediaries' problem is given by

$$
q_{t}=\frac{\Phi_{t}\left(R_{t}^{m}, \rho_{t}\right)}{1+\Phi_{t}\left(R_{t}^{m}, \rho_{t}\right)},
$$

where

$$
\Phi_{t}\left(R_{t}^{m}, \rho_{t}\right)=\frac{1-\pi}{\pi}\left(\frac{R_{t}^{m}}{\rho_{t}}\right)^{\frac{\gamma}{1+\gamma}}
$$

It is easy to verify from equations (8) and (9) that $\frac{\partial q_{t}}{\partial R_{t}^{m}}>0$ and $\frac{\partial q_{t}}{\partial \rho_{t}}<0$. Intuitively, an increase in the rate of inflation decreases the relative rate of return $\left(\frac{R_{t}^{m}}{\rho_{t}}\right)$ of the two assets. This, on one hand, induces intermediaries to allocate a larger fraction of funds to lending. On the other hand, an increase in inflation causes intermediaries to increase money holding in their portfolio in order to guarantee adequate provision of liquidity services to those agents for whom the relocation shock has realized. The latter effect dominates the former when the degree of risk aversion is large enough (i.e., $\gamma>0$ ). Following a similar line of argument, it is straightforward to explain the inverse relationship between $q_{t}$ and $\rho_{t}$.

\subsubsection{Information friction and the Lending Rate}

We assume that there exists an informational friction between the capital-producing firms and the financial intermediaries that takes the form of a moral hazard problem. In particular, after receiving a loan, a capital-producing firm may wish not to undertake the project and instead run away with a fraction $0<\lambda \leq 1$ of the loan that it is able to store for future consumption. In such circumstance, it is possible for the lender to track the borrower down only at a prohibitively high cost. To avoid apprehension and the penalty, a firm must remain underground for the rest of its life. Thus, by absconding, a firm loses opportunities of either running its own project or supplying labor to the market during adulthood. Evidently, while designing the contract, a 
financial intermediary must take into account the fact that the expected payoff to firms from defaulting must be no greater than the expected payoff from not defaulting, if defaulting is not, in fact to occur. That is, $\left(x r_{t+1}-\rho_{t}\right) l_{t}+p\left(k_{t}\right) \delta w_{t+1} \geq \lambda l_{t}$, where $l_{t}$ denotes the loan amount. Given that financial intermediaries are maximizing depositor's utility, it is easy to establish that such incentive compatibility constraint would always bind. Hence, the real rate of return that the financial intermediaries are able to enjoy from lending is given by

$$
\rho_{t}=x r_{t+1}+\frac{p\left(k_{t}\right) \delta w_{t+1}}{l_{t}}-\lambda=A \alpha(1+\kappa) x+\frac{p\left(k_{t}\right) \delta A(1-\alpha) k_{t+1}}{l_{t}}-\lambda .
$$

It is worth noting that among other things $\rho_{t}$ is influenced by the state variables. It is this feature that we exploit in our analysis for establishing the linkage between the stages of development and the relative merits of seigniorage vis-à-vis taxation financing of public spending.

\subsection{Government}

In this economy, the government relies on two sources of revenue to finance its non-productive expenditure, $G_{t}$. The first source of revenue comes from levying proportional taxes on wage earnings. Recall that at each time period, a unity measure of young and $\kappa$ measure of old households earn wage incomes. Accordingly, the total tax revenue collected during period $t$ is given by $(1+\kappa) \tau w_{t}$. The second source of the government's revenue is through seigniorage. Let $M_{t}$ and $P_{t}$ denote the time $t$ money supply and price level, respectively. Then, the government's budget constraint is given by

$$
G_{t}=(1+\kappa) \tau w_{t}+\frac{M_{t}-M_{t-1}}{P_{t}} .
$$

Finally, to ensure balanced growth, we assume $G_{t}=\beta Y_{t}$. That is, the government spends a constant fraction $(\beta)$ of the total output where $\beta$ is viewed as a policy parameter.

\section{Balanced Growth Path}

The economy's capital at time $t+1$ originates from the project run by the capitalproducing firms at time period $t$. Each of these firms converts $l_{t}$ amount of time $t$ output 
(obtained from the financial intermediaries in the form of a loan) into $x l_{t}$ amount of $t+1$ capital. Making use of equation (3) and noting that $l_{t}=q_{t}(1-\tau) w_{t}$ and that there is unity measure of output-producing firms at each time period, we express the growth rate of the capital stock per firm as,

$$
\theta \equiv \frac{k_{t+1}}{k_{t}}=A(1-\alpha)(1-\tau) x q\left(R_{t}^{m}, \rho_{t}\right),
$$

where $q_{t}$ is given by equation (8).

As noted earlier, the demand for liquidity in our model originates from the relocation needs of the depositors. A financial intermediary makes provisions for such needs by allocating $\left(1-q_{t}\right)$ fraction of the deposit to real money balances. Accordingly, for a given value of $q_{t}$, the aggregate stock of real balances at time $t$ satisfies

$$
m_{t} \equiv \frac{M_{t}}{p_{t}}=\left[1-q_{t}\left(R_{t}^{m}, \rho_{t}\right)\right](1-\tau) w_{t}=\left[1-q_{t}\left(R_{t}^{m}, \rho_{t}\right)\right](1-\tau)(1-\alpha) A k_{t},
$$

implying that $m_{t}$ grows at the same rate as $k_{t}$. Next, a time lead of the government's budget constraint in equation (11) together with the fact that $G_{t}=\beta Y_{t}$ yields

$$
\beta Y_{t+1}=(1+\kappa) \tau w_{t+1}+m_{t+1}-m_{t} \frac{P_{t}}{P_{t+1}} .
$$

Finally, making use of equations (3), (12), (13), and the facts that $m_{t+1}=\theta m_{t}$ and that $Y_{t}=A(1+\kappa) k_{t}$, we rewrite equation (14) as

$$
\beta=(1-\alpha) \tau+\frac{1-q_{t}\left(R_{t}^{m}, \rho_{t}\right)}{A x q_{t}\left(R_{t}^{m}, \rho_{t}\right)(1+\kappa)}\left(\theta-R_{t}^{m}\right) .
$$

Recognize that the first term on the right-hand-side of equation (15) represents the fraction of government spending financed with income tax revenue, while the second term denotes the fraction of the revenue collected through seigniorage. Moreover, the second term can be further decomposed into the inflation tax base $\frac{1-q_{t}\left(R_{t}^{m}, \rho_{t}\right)}{A x q_{t}\left(R_{t}^{m}, \rho_{t}\right)(1+\kappa)}$ and the inflation tax rate $\left(\theta-R_{t}^{m}\right)$. 
For evaluating the growth effects of government expenditure, we consider equations (12) and (15) jointly and present our results in the following propositions. ${ }^{3}$

Proposition 1. For a given $\rho_{t}$, an increase in government expenditures financed either through an increase in income taxes or seigniorage reduces the rate of economic growth.

\section{Proof. See Appendix A.}

The intuition underlying the above proposition is straightforward. An increase in the income tax rate lowers the growth rate of capital formation by directly decreasing the volume of deposited funds and the volume of lending. In contrast, the effect of an increase in the seigniorage on the growth rate is obtained through portfolio choice of the financial intermediaries. Given that $q^{\prime}\left(R^{m}\right)>0$, an increase in inflation induces financial intermediaries to shift their portfolios in favor of real balances and against lending. This, in turn, lowers the rate of growth of the economy.

The result that both methods of financing generate distortionary effects on growth is not surprising and has been widely established in previous works (e.g. Palivos and Yip 1995, Espinosa-Vega and Yip 1999, 2000). The question of interest here is which of these two methods generates relatively less distortionary effects? In answering this question we depart from the existing views by claiming in the following proposition that the appropriate choice of the financing method depends significantly on the level of the economic development.

Proposition 2. For a large (small) enough $k_{t}$, an increase in government expenditure financed through seigniorage generates relatively less (more) distortionary effects on growth.

Proof. Given that $l_{t}=q_{t}(1-\tau) w_{t}=q_{t}(1-\tau) A(1-\alpha) k_{t}$, equations (10) and (12) together imply $\rho_{t}=A x\left[\alpha(1+\kappa)+(1-\alpha) \delta p\left(k_{t}\right)\right]-\lambda$. From equations (A3) and (A4), a direct comparison of the growth effects yields that seigniorage is relatively less (more) distortionary when $\frac{1}{1+\kappa}\left(1+\frac{R_{t}^{m}}{\gamma \theta_{t}}\right)>(<) 1$. Further, equations (8), (9), and (12) together imply that $\theta_{t}$ is decreasing

\footnotetext{
${ }^{3}$ We skip the formal proof of the fact that the economy is characterized by a unique non-trivial balanced growth path. The proof is available upon request. Alternately refer to Espinosa-Vega and Yip (1999).
} 
in $\rho_{t}$ and hence in $k_{t}$. Accordingly, when $k_{t}$ is large enough (equivalently, for a small enough $\theta_{t}$ ) financing through seigniorage produces relatively less distortionary growth effects than that obtained under tax financing. The opposite is true when $k_{t}$ is small.

Recall that the growth effect of seigniorage depends on the portfolio choices of the financial intermediaries which are determined by the relative rate of return of the two assets. For a developed country where the return from investment $\left(\rho_{t}\right)$ is high due to low default risk, the relative return $\left(\frac{R_{t}^{m}}{\rho_{t}}\right)$ is less sensitive to the movement in $R_{t}^{m}$, resulting in a smaller negative growth effect of seigniorage compared to that one would obtain in the case of a developing country.

Finally, we note that it is necessary to assume that $\rho_{t}>R_{t}^{m}$ holds throughout our analysis. In its absence, lending to the capital-producing firms is not a preferred option. At the same time, since $p\left(k_{t}\right) \rightarrow 1$ as $k_{t} \rightarrow \infty$, the upper bound of $\rho_{t}$ is set at $A x[\alpha(1+\kappa)+(1-\alpha) \delta]-\lambda$. For our story to be meaningful, the value of $\rho_{t}$ for which the growth effects of seigniorage and taxation financing are equal (i.e., the relation $\frac{1}{1+\kappa}\left(1+\frac{R_{t}^{m}}{\gamma \theta_{t}}\right)=1$ holds) must lie in the domain of $\rho_{t}$ specified above. In Table A1 (Appendix A), we have listed three parameter constellations for which the above requirement is satisfied both in the case of an inflationary and a deflationary situation. Part of these parameter constellations (e.g., the values of $\gamma, \tau, A$, and $\alpha$ ) has been chosen on the basis of previous studies and is indicated clearly in the table.

\section{Empirical Analysis}

The theoretical analysis conducted above yields a direct testable implication. The analysis suggests that, for the high-income economies, an expansion in government expenditures financed with taxes retards growth more than if it were financed through seigniorage. An opposite result holds in the case of low-income countries. In this section, we proceed to test this hypothesis using a panel data set of 21 OECD countries and 40 developing countries for the 
period 1972-1999. For isolating and contrasting the growth effects of public expenditure when financed through taxation vis-à-vis seigniorage we base our methodology on the previous works by Miller and Russek (1997), Kneller et al. (1999), and Bleaney et al. (2001). These papers hold the view that an evaluation of the effects of taxes, expenditures, and budget deficit/surplus on economic growth is meaningful only when both the sources and the uses of government funds are included simultaneously in the analysis. In line with this argument, we employ the following model specification:

$$
g_{i t}=\alpha+\sum_{i=1}^{m} \beta_{i} M_{i t}+\sum_{j=1}^{n} \gamma_{j} N_{j t}+u_{i t}
$$

where $g_{i t}$ denotes growth in country $i$ at time $t, M_{i t}$ represents non-fiscal conditioning variables that commonly appear in growth regressions. Conditioning variables include initial GDP, investment, population growth rate, initial secondary schooling, trade, and the terms of trade growth rate. ${ }^{4} N_{j t}$ describes the government budget elements. To make the analysis consistent with our theory counterpart, we decompose the government budget into four elements in accordance with the following consolidated government sector budget identity:

$$
E_{i t}=R_{i t}+S_{i t}+D_{i t}
$$

The left hand side $\left(E_{i t}\right)$ consists of government expenditure on goods, services and transfers plus interest payments on the outstanding debt, and the right hand side consists of tax revenue and grants $\left(R_{i t}\right)$ plus the seigniorage $\left(S_{i t}\right)$ used to finance the budget plus the rest of the budget financing $\left(D_{i t}\right)$ of which new issues of interest bearing debt constitute a significant part. Inclusion of all four elements in equation (16) would give rise to perfect collinearity arising from the identity of the budget constraint. As a result, (at least) one of the above four elements of the budget must be omitted from the specification. Following the methodology proposed by Miller and Russek (1997) and maintaining consistency with our theory, we exclude seigniorage $\left(S_{i t}\right)$ from equation (17) to obtain

$$
g_{i t}=\alpha+\sum_{i=1}^{m} \beta_{i} M_{i t}+\delta_{1} E_{i t}+\delta_{2} R_{i t}+\delta_{3} D_{i t}+u_{i t}
$$

\footnotetext{
${ }^{4}$ The initial level of income has consistently been used in growth regressions to capture conditional convergence to the steady-state, while controlling for human capital (schooling) allows for proxying the divergence of the initial income level from its steady-state level (Cashin 1995). The rest of the conditioning variables have been widely used and found significant in a number of Barro-type regressions.
} 
The exclusion of $S_{i t}$ allows seigniorage to change freely. The estimated coefficient of public expenditures $\left(\delta_{1}\right)$ then captures the effect on economic growth of an increase in government expenditure, assuming no changes in the tax revenue or other forms of financing. In other words, when the excluded element is a source of government revenue, it becomes the implicit financing element of government expenditure. We capture the growth effects of tax-financed government expenditure according to the following two ways. First, we capture the effect by summing up the estimates of $\delta_{1}$ and $\delta_{2}$ in equation (18) and construct a confidence interval for their sum. ${ }^{5}$ As an alternative procedure, we focus on the estimate of the expenditure coefficient in a regression where (instead of seigniorage) the omitted variable is the tax revenue. For completeness, we have chosen to report the results obtained by both methods.

\subsection{The Data}

Our data set consists of panel data for 21 developed OECD member countries and 40 developing countries over the period 1972-1999. Observations are drawn from three different sources. Government budget data and the seigniorage measures have been drawn from the International Monetary Fund's (IMF) Government Finance Statistics and the International Financial Statistics, respectively. The data on the rest of the variables have been drawn from the World Bank's World Development Indicators. Unless we state otherwise, the observations correspond to the three-year and five-year average values of the variables in the time intervals 1972-74 and 1975-1999, respectively. We follow this approach to capture the long-run trends by eliminating business cycle effects. ${ }^{6}$ It is often difficult to obtain a direct measure of government borrowing that is used to finance its expenditure. Following Rodriguez (1994), we have used the difference between the two series (the deficit of the consolidated public sector and the revenue from money creation) as a proxy of the part of the total expenditure that is financed by issuing interest-bearing debt. In Table 1 we summarize the descriptive statistics of the variables used in the baseline regressions. The Appendix B provides the detailed description and the sources of the variables used in the analysis.

\footnotetext{
${ }_{6}^{5}$ Refer to Miller and Russek (1997), Kneller et al. (1999), and Bleaney et al. (2001) for a more detailed discussion.

${ }^{6}$ A similar approach has been adopted in Cashin (1995), Mendoza et al. (1997), Kneller et al. (1999), and Bleaney et al. (2001).
} 
Table 1. Descriptive Statistics

\begin{tabular}{|c|c|c|c|c|c|c|c|c|}
\hline \multirow[b]{2}{*}{ Variable } & \multicolumn{2}{|c|}{ Mean } & \multicolumn{2}{|c|}{ Standard Deviation } & \multicolumn{2}{|c|}{ Minimum } & \multicolumn{2}{|c|}{ Maximum } \\
\hline & $\begin{array}{l}\text { Deve- } \\
\text { loped }\end{array}$ & $\begin{array}{l}\text { Deve- } \\
\text { loping }\end{array}$ & $\begin{array}{l}\text { Deve- } \\
\text { loped }\end{array}$ & $\begin{array}{l}\text { Deve- } \\
\text { loping }\end{array}$ & $\begin{array}{l}\text { Deve- } \\
\text { loped }\end{array}$ & $\begin{array}{l}\text { Deve- } \\
\text { loping }\end{array}$ & $\begin{array}{l}\text { Deve- } \\
\text { loped }\end{array}$ & $\begin{array}{l}\text { Deve- } \\
\text { loping }\end{array}$ \\
\hline GDP p.c. growth (\%) & 0.0236 & 0.0189 & 0.0069 & 0.0186 & 0.0089 & -0.0166 & 0.0412 & 0.0599 \\
\hline $\begin{array}{l}\text { Initial p.c. GDP } \\
\text { (1995 US dollars) }\end{array}$ & 20,726 & 2,085 & 7,300 & 2,435 & 7,976 & 97.86 & 40,787 & 13,344 \\
\hline Investment & 0.2326 & 0.2297 & 0.0257 & 0.0579 & 0.1892 & 0.1207 & 0.2837 & 0.3960 \\
\hline $\begin{array}{l}\text { Population growth } \\
(\%)\end{array}$ & 0.0059 & 0.0216 & 0.0035 & 0.0073 & 0.0017 & -0.0007 & 0.0141 & 0.0346 \\
\hline Government revenues & 0.3296 & 0.2242 & 0.0780 & 0.0838 & 0.1930 & 0.1028 & 0.4821 & 0.4881 \\
\hline $\begin{array}{l}\text { Government } \\
\text { expenditures }\end{array}$ & 0.3538 & 0.2463 & 0.0808 & 0.0889 & 0.2168 & 0.1077 & 0.5088 & 0.5228 \\
\hline Seigniorage & 0.0101 & 0.0249 & 0.0099 & 0.0174 & 0.0036 & 0.0014 & 0.0385 & 0.0798 \\
\hline $\begin{array}{l}\text { Rest of budget } \\
\text { financing }\end{array}$ & 0.0230 & 0.0059 & 0.0225 & 0.0299 & -0.0253 & -0.0685 & 0.0833 & 0.0689 \\
\hline $\begin{array}{l}\text { Initial secondary } \\
\text { schooling }\end{array}$ & 0.8980 & 0.3980 & 0.1103 & 0.2054 & 0.6391 & 0.3741 & 1.0505 & 0.8482 \\
\hline Trade & 0.6921 & 0.6324 & 0.3867 & 0.5207 & 0.1897 & 0.1592 & 1.9769 & 3.4418 \\
\hline $\begin{array}{l}\text { Terms of trade } \\
\text { growth }(\%)\end{array}$ & -0.0007 & -0.0573 & 0.0030 & 0.0099 & -0.0061 & -0.2336 & 0.0055 & 3.924 \\
\hline
\end{tabular}

Notes: Descriptive statistics for the variables used in baseline regressions as time interval average values. Variables are expressed as fractions of GDP except where noted. Seigniorage measured as Seigniorage1 described in Appendix B. Missing three-year and five-year averages for 1972-1974 (Portugal, Cameroon, Egypt, Iran, Singapore, Syrian Arab Rep., Venezuela, Zimbabwe), 1972-1979 (Argentina, Hungary, Indonesia, Lesotho), 1972-1984 (Bolivia), 1972-1989 (Germany, Romania, South Africa), 1975-1979 (Brazil), 1985-1989 (Switzerland, Burundi), 1985-1999 (Senegal), 1990-1999 (Zambia), 1995-1999 (Austria, Burkina Faso, Paraguay), 1972-1984 \& 1995-1999 (Ethiopia), 1985-1989 \& 1995-1999 (Gambia).

\subsection{Baseline Results}

We consider five special forms of panel data estimation: pooled OLS, one-way and twoway fixed effects, and one-way and two-way random effects models. In all cases, the random effects specification received the greatest support from the diagnostic tests for both the developed and developing country samples. ${ }^{7}$ Accordingly, in Table 2, we report the results of the random effects model run on the basis of the specification (equation 18), in which seigniorage has been considered as the implicit financing element of the public expenditure. The first and the second column of the table describe the results for the developed and developing countries, respectively.

\footnotetext{
${ }^{7}$ The selection of the model between pooled OLS and fixed effects relies on an F-test of the joint significance of the cross section and/or time dummies present in the fixed effects model. Model selection between the fixed and random effects has been based on the Hausman model specification test. Our bias towards the random effects model is shared by a number of authors (e.g., Cashin 1995, Wooldridge 2002).
} 
We open the discussion with the results for the non-fiscal variables. Many of these results are in accordance with the results obtained by previous studies. For example, as in Barro 1991, Mankiw, Romer, and Weil 1992, Miller and Russek 1997, and Kneller et al. 1999, we find evidence of conditional convergence in both samples suggesting that countries with low initial income levels grow faster than countries with higher initial income levels. Similarly, we find that the investment and the population variables are significantly associated with economic growth with a positive and a negative coefficient, respectively. Such associations are more pronounced for the developing countries than for the developed countries. We find that the coefficient of the initial schooling to be insignificant for both sets of countries. This result is supported by many previous findings. Examples include Levine and Renelt (1992), Cashin (1995), and Gupta et.al. (2005).

Table 2. Regression results with total government revenues

\begin{tabular}{|c|c|c|}
\hline \multicolumn{3}{|c|}{ Dependent variable: GDP p.c. growth } \\
\hline Country Set & Developed & Developing \\
\hline Log of initial p.c. GDP & $\begin{array}{c}-0.017 * * \\
(2.26)\end{array}$ & $\begin{array}{c}-0.014 * * \\
(2.51)\end{array}$ \\
\hline Investment & $\begin{array}{c}0.117 * * * \\
(3.03)\end{array}$ & $\begin{array}{c}0.195 * * * \\
(4.63)\end{array}$ \\
\hline Population growth & $\begin{array}{c}-0.584 * * \\
(2.09)\end{array}$ & $\begin{array}{c}-0.684^{*} \\
(1.66)\end{array}$ \\
\hline Government expenditures & $\begin{array}{r}-0.089 \\
(1.08)\end{array}$ & $\begin{array}{c}-0.165 * * \\
(2.39)\end{array}$ \\
\hline Government revenues & $\begin{array}{r}-0.028 \\
(0.33)\end{array}$ & $\begin{array}{l}0.091 \\
(1.06)\end{array}$ \\
\hline Rest of budget financing & $\begin{array}{l}-0.032 \\
(0.42)\end{array}$ & $\begin{array}{l}0.103 \\
(1.59)\end{array}$ \\
\hline Initial secondary schooling & $\begin{array}{l}0.007 \\
(0.80)\end{array}$ & $\begin{array}{l}-0.012 \\
(0.65)\end{array}$ \\
\hline Trade & $\begin{array}{c}0.038 * * * \\
(4.96)\end{array}$ & $\begin{array}{l}0.004 \\
(0.48)\end{array}$ \\
\hline Terms of trade growth & $\begin{array}{l}0.125 \\
(1.34)\end{array}$ & $\begin{array}{c}0.146 * * \\
(2.19)\end{array}$ \\
\hline R-square & 0.3722 & 0.2095 \\
\hline No. of observations & 119 & 199 \\
\hline F-test & $15.77 * * *$ & $2.94 *$ \\
\hline Hausman specification test & 10.12 & 14.06 \\
\hline Confidence interval at $95 \%$ & $(-0.167,-0.069)$ & $(-0.144,-0.003)$ \\
\hline Estimated effect of tax finance & $\begin{array}{c}-0.119 * * * \\
(4.09)\end{array}$ & $\begin{array}{c}-0.100 * * \\
(2.39)\end{array}$ \\
\hline
\end{tabular}


Finally, although the trade and the terms of trade variables appear with the predicted signs in both the samples, the trade variable is significant only in the case of developed countries, whereas the terms of trade appears to be significant only in the case of developing countries. ${ }^{8}$

Turning our attention to the fiscal variables, we find strong evidence in support of our theoretical predictions. Given that seigniorage is the implicit financing element, the coefficient of total expenditure captures the growth effects of public expenditure when financed through seigniorage. The table indicates that such growth effect is large and significantly negative in the case of developing countries. In contrast, the same coefficient is found to be insignificant for developed countries. To obtain the growth effect of public expenditure when financed through taxes, we calculate the sum of the estimated coefficients on government revenues and expenditures. As the above table indicates, the F-test of their joint significance cannot be rejected for either set of countries, and the 95 percent confidence interval suggests that tax financed government expenditures have a significantly negative growth effect on both sets of countries. As an alternative procedure, we have also estimated growth regressions by excluding tax revenues and by including seigniorage from the equation (18) so that tax financing now becomes the implicit financing element of government expenditures. ${ }^{9}$ In this case, we have reported the coefficient of total (public) expenditures in the last row of the table. As before, we find that the results are in accordance with the predictions of our theoretical model.

To obtain further insights, we have repeated the above exercises after decomposing the total public revenues into income tax, other distortionary taxes, non-distortionary taxes, and other revenues. ${ }^{10}$ The results are reported in Table 3. The first two columns of the table report the results for the two sets of countries where revenue has been decomposed into distortionary taxes, non-distortionary taxes, and other revenues. In the next two columns, the distortionary tax revenues have been further disaggregated into income tax revenues and other distortionary tax

\footnotetext{
${ }^{8}$ In addition to the above non-fiscal conditioning variables, we have also run regressions that include the rate of inflation as an explanatory variable in order to disentangle the effect of seigniorage finance of spending on growth from any possible effect of inflation on growth. Although inflation is found to be negatively associated with growth for both sets of countries in a significant way, the effects of the remaining fiscal and non-fiscal variables remain similar to those reported in Table 2. A similar result is also obtained when we include a dummy variable for Latin American countries to control for their different growth experiences during the period under consideration.

${ }^{9}$ To economize on space we do not report the entire results. They are available upon request.

${ }^{10}$ We follow Kneller et al. (1999) in classifying the government revenues into distortionary taxes (taxes on income, profits, and capital gains, on social security contributions, on payroll or workforce, and on property), nondistortionary taxes (taxes on domestic goods and services), and other revenues (taxes on international trade and transactions, non-tax revenues, other tax revenues, and grants). Summary statistics on these and the rest of the new variables used in the sensitivity analysis section are reported in Appendix B.
} 
revenues. As before, the last two rows in column 1 and 2 report the estimated growth effects of public expenditure when it is financed by distortionary taxes (instead of seigniorage). Similarly, the last two rows in columns 3 and 4 provide the estimated growth effects of public expenditure when income tax is the implicit financing element. As the table shows, the direction of results still remains intact (if not improves) when we disaggregate the revenue data.

Table 3. Regression results with distortionary taxes and income taxes

\begin{tabular}{|c|c|c|c|c|}
\hline \multicolumn{5}{|c|}{ Dependent variable: GDP p.c. growth } \\
\hline Country Set & Developed & Developing & Developed & Developing \\
\hline \multirow[t]{2}{*}{ Log of initial p.c. GDP } & $-0.015 * *$ & $-0.012 * *$ & $-0.014 *$ & $-0.012 * *$ \\
\hline & $(1.85)$ & $(2.05)$ & $(1.78)$ & $(2.10)$ \\
\hline \multirow[t]{2}{*}{ Investment } & $0.114 * * *$ & $0.191 * * *$ & $0.114 * * *$ & $0.199 * * *$ \\
\hline & $(2.94)$ & $(4.50)$ & $(2.89)$ & $(4.66)$ \\
\hline \multirow[t]{2}{*}{ Population growth } & $-0.572 * *$ & $-0.751 *$ & $-0.576^{*}$ & $-0.669 *$ \\
\hline & $(1.96)$ & $(1.85)$ & $(1.94)$ & $(1.64)$ \\
\hline \multirow[t]{2}{*}{ Government expenditures } & -0.029 & $-0.141 * *$ & -0.026 & $-0.154 * *$ \\
\hline & $(0.36)$ & $(2.21)$ & $(0.31)$ & (2.39) \\
\hline \multirow[t]{2}{*}{ Distortionary tax revenues } & -0.131 & 0.004 & & \\
\hline & (1.40) & $(0.04)$ & - & - \\
\hline \multirow[t]{2}{*}{ Income tax revenues } & - & 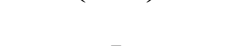 & -0.139 & -0.074 \\
\hline & - & - & (1.46) & $(0.62)$ \\
\hline \multirow{2}{*}{$\begin{array}{l}\text { Other distortionary tax } \\
\text { revenues }\end{array}$} & 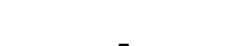 & 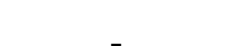 & -0.137 & 0.201 \\
\hline & - & - & $(1.21)$ & $(1.15)$ \\
\hline \multirow{2}{*}{$\begin{array}{l}\text { Non-distortionary tax } \\
\text { revenues }\end{array}$} & -0.012 & 0.075 & -0.014 & 0.062 \\
\hline & $(0.12)$ & $(0.79)$ & $(0.13)$ & $(0.49)$ \\
\hline \multirow[t]{2}{*}{ Other revenues } & -0.077 & 0.087 & -0.076 & 0.085 \\
\hline & $(0.77)$ & $(0.97)$ & $(0.75)$ & $(0.95)$ \\
\hline \multirow[t]{2}{*}{ Rest of budget financing } & -0.082 & $0.111^{*}$ & -0.085 & $0.112^{*}$ \\
\hline & $(1.12)$ & $(1.80)$ & $(1.12)$ & $(1.82)$ \\
\hline \multirow[t]{2}{*}{ Initial secondary schooling } & 0.006 & -0.011 & 0.006 & -0.010 \\
\hline & $(0.72)$ & $(0.54)$ & $(0.70)$ & $(0.55)$ \\
\hline \multirow[t]{2}{*}{ Trade } & $0.042 * * *$ & 0.004 & $0.043 * * *$ & 0.006 \\
\hline & $(4.93)$ & $(0.48)$ & $(4.90)$ & $(0.60)$ \\
\hline \multirow[t]{2}{*}{ Terms of trade growth } & 0.136 & $0.151 * *$ & 0.139 & $0.158 * *$ \\
\hline & $(1.47)$ & $(2.27)$ & $(1.49)$ & $(2.38)$ \\
\hline R-square & 0.3973 & 0.2140 & 0.4017 & 0.2215 \\
\hline No. of observations & 119 & 198 & 119 & 198 \\
\hline F-test & $16.65 * * *$ & 2.64 & $8.55 * * *$ & $4.78 * *$ \\
\hline Hausman specification test & 11.35 & 12.29 & 11.29 & 11.39 \\
\hline Confidence interval at $95 \%$ & $(-0.226,-0.095)$ & $(-0.275,0.002)$ & $(-0.260,-0.072)$ & $(-0.400,-0.056)$ \\
\hline Estimated effect of & $-0.129 * * *$ & -0.119 & $-0.125 * *$ & -0.111 \\
\hline distortionary tax finance & (3.83) & $(1.62)$ & $(2.46)$ & $(1.34)$ \\
\hline
\end{tabular}

$* * *, * *, *$ : Significant at 1\%, 5\%, and 10\% level, respectively. t-statistics in parentheses.

\section{Sensitivity Analysis}

This section examines the robustness of our baseline results by conducting the following three exercises. First, we consider alternative seigniorage measures to examine the validity of our results. Second, it is often the case that the estimated coefficients of the fiscal variables are 
sensitive to the inclusion/exclusion of the initial income levels (Easterly and Rebelo 1993). We examine whether our results are sensitive to the omission of initial income from the set of conditioning variables. Finally, we account for potential endogeneity between the growth rate and the explanatory regressors.

\subsection{Alternative Seigniorage Measures}

The measurement of seigniorage has been an issue of a long debate in the literature and a number of alternative estimates have been proposed to measure its magnitude ${ }^{11}$. Below, we examine the validity of our result with respect to some of these alternate measures that are appropriate for both developed and developing countries. ${ }^{12}$ The full description of these measures and their summary statistics appear in Appendix B.

Table 4. Regression results for developed countries with alternative seigniorage measures

\begin{tabular}{|c|c|c|c|c|}
\hline \multicolumn{5}{|c|}{ Dependent variable: GDP p.c. growth } \\
\hline Seigniorage measure & Seigniorage1 & Seigniorage2 & Seigniorage3 & Seigniorage4 \\
\hline \multirow[t]{2}{*}{ Log of initial p.c. GDP } & $-0.017 * *$ & $-0.017 * *$ & $-0.017 * *$ & $-0.017 * *$ \\
\hline & $(2.26)$ & $(2.26)$ & $(2.29)$ & $(2.31)$ \\
\hline \multirow[t]{2}{*}{ Investment } & $0.117 * * *$ & $0.121 * * *$ & $0.118 * * *$ & $0.117 * * *$ \\
\hline & $(3.03)$ & $(3.12)$ & $(3.01)$ & $(3.01)$ \\
\hline \multirow[t]{2}{*}{ Population growth } & $-0.584 * *$ & $-0.571 * *$ & -0.578 & -0.578 \\
\hline & $(2.09)$ & $(2.05)$ & $(2.07)$ & $(2.07)$ \\
\hline \multirow[t]{2}{*}{ Government expenditures } & -0.089 & -0.022 & -0.106 & -0.107 \\
\hline & (1.08) & $(0.23)$ & (1.24) & (1.18) \\
\hline \multirow[t]{2}{*}{ Government revenues } & -0.028 & -0.094 & -0.013 & -0.013 \\
\hline & $(0.33)$ & $(0.94)$ & $(0.16)$ & $(0.14)$ \\
\hline \multirow[t]{2}{*}{ Rest of budget financing } & -0.032 & -0.101 & -0.013 & -0.013 \\
\hline & $(0.42)$ & $(1.11)$ & $(0.17)$ & $(0.15)$ \\
\hline \multirow[t]{2}{*}{ Initial secondary schooling } & 0.007 & 0.006 & 0.007 & 0.006 \\
\hline & $(0.80)$ & $(0.76)$ & $(0.79)$ & $(0.77)$ \\
\hline \multirow[t]{2}{*}{ Trade } & $0.038 * * *$ & $0.038 * * *$ & $0.039 * * *$ & $0.039 * * *$ \\
\hline & $(4.96)$ & $(4.96)$ & $(5.04)$ & $(5.05)$ \\
\hline \multirow[t]{2}{*}{ Terms of trade growth } & 0.125 & 0.122 & 0.126 & 0.126 \\
\hline & $(1.34)$ & $(1.32)$ & $(1.35)$ & $(1.34)$ \\
\hline R-square & 0.3722 & 0.3790 & 0.3718 & 0.3711 \\
\hline No. of observations & 119 & 119 & 119 & 119 \\
\hline F-test & $15.77 * * *$ & $16.04 * * *$ & $16.53 * * *$ & $17.20 * * *$ \\
\hline Hausman specification test & 10.12 & 10.53 & 10.16 & 10.47 \\
\hline Confidence interval at $95 \%$ & $(-0.167,-0.069)$ & $(-0.165,-0.068)$ & $(-0.169,-0.071)$ & $(-0.168,-0.072)$ \\
\hline Estimated effect of tax & $-0.119 * * *$ & $-0.116^{* * *}$ & $-0.120 * * *$ & $-0.117 * * *$ \\
\hline finance & (4.09) & (4.03) & $(4.21)$ & $(4.28)$ \\
\hline
\end{tabular}

$* * *, * *, *$ : Significant at $1 \%, 5 \%$, and $10 \%$ level, respectively. t-statistics in parentheses.

\footnotetext{
${ }^{11}$ For a discussion on this issue see Drazen 1985, Klein and Neumann 1990, de Haan, Zelhorst, and Roukens 1993 , and Honohan 1996.

${ }^{12}$ We have not considered the measure of seigniorage that is given by the ratio of the product of inflation and highpowered money to nominal GDP as it is often considered inappropriate for developing countries (see Walsh 1998). Also, we have abstained from considering the opportunity cost concept of seigniorage given by the ratio of the product of nominal interest rate and high-powered money to nominal GDP. The difficulty associated with this latter measure is that it requires the choice of the "correct" nominal interest rate across countries and time.
} 
In Table 4, we report the regression results for the developed countries by using three alternative seigniorage measures as indicated by Seigniorage2, Seigniorage3, and Seigniorage4. For a ready comparison, we reproduce in the first column the results from Table 2 where Seigniorage 1 had been used in the regression. As it can be seen in Table 4, for all measures of seigniorage, our previously obtained results remain intact for the set of developed countries. Similarly, as shown in the Table 5, except for the measure Seigniorage 2, the results are preserved for the set of developing countries.

Table 5. Regression results for developing countries with alternative seigniorage measures

\begin{tabular}{lcccc}
\hline Dependent variable: GDP p.c. growth & & & \\
\hline Seigniorage measure & Seigniorage & Seigniorage2 & Seigniorage3 & Seigniorage4 \\
\hline Log of initial p.c. GDP & $-0.014^{* *}$ & $-0.015^{* * *}$ & $-0.014^{* * *}$ & $-0.014^{* *}$ \\
& $(2.51)$ & $(2.60)$ & $(2.48)$ & $(2.48)$ \\
Investment & $0.195^{* * *}$ & $0.194^{* * *}$ & $0.198^{* * *}$ & $0.105^{* * *}$ \\
& $(4.63)$ & $(4.65)$ & $(4.63)$ & $(2.63)$ \\
Population growth & $-0.684^{*}$ & $-0.746^{*}$ & $-0.664^{*}$ & $-0.934^{* *}$ \\
& $(1.66)$ & $(1.81)$ & $(1.61)$ & $(2.23)$ \\
Government expenditures & $\mathbf{- 0 . 1 6 5 * *}$ & $\mathbf{- 0 . 1 8 7 * * *}$ & $\mathbf{- 0 . 1 4 4 *}$ & $\mathbf{- 0 . 2 9 4 * * *}$ \\
& $\mathbf{( 2 . 3 9 )}$ & $\mathbf{( 2 . 7 3 )}$ & $\mathbf{( 1 . 6 6 )}$ & $\mathbf{( 4 . 1 0 )}$ \\
Government revenues & $\mathbf{0 . 0 9 1}$ & $\mathbf{0 . 1 2 1}$ & $\mathbf{0 . 0 6 3}$ & $\mathbf{0 . 2 0 0 * *}$ \\
& $\mathbf{( 1 . 0 6 )}$ & $\mathbf{( 1 . 4 2 )}$ & $\mathbf{( 0 . 6 2 )}$ & $(\mathbf{2 . 2 6 )}$ \\
Rest of budget financing & 0.103 & $0.144^{* *}$ & 0.051 & $0.224^{* * *}$ \\
& $(1.59)$ & $(2.37)$ & $(0.57)$ & $(3.51)$ \\
Initial secondary schooling & -0.012 & -0.010 & -0.013 & -0.014 \\
& $(0.65)$ & $(0.52)$ & $(0.69)$ & $(0.79)$ \\
Trade & 0.004 & 0.004 & 0.004 & 0.007 \\
& $(0.48)$ & $(0.46)$ & $(0.45)$ & $(0.76)$ \\
Terms of trade growth & $0.146^{* *}$ & $0.144^{* *}$ & $0.148^{* *}$ & 0.123 \\
& $(2.19)$ & $(2.19)$ & $(2.19)$ & $(1.83)$ \\
R-square & 0.2095 & 0.2207 & 0.2011 & 0.2163 \\
No. of observations & 199 & 199 & 199 & 194 \\
F-test & $2.94^{*}$ & 2.31 & $3.58^{*}$ & $4.94^{* *}$ \\
Hausman specification test & 14.06 & 14.07 & 13.53 & 12.90 \\
Confidence interval at $95 \%$ & $(-0.144,-0.003)$ & $(-0.136,0.005)$ & $(-0.152,-0.010)$ & $(-0.164,-0.024)$ \\
Estimated effect of tax & $-0.098^{* *}$ & -0.039 & $-0.098^{* *}$ & $-0.086^{* *}$ \\
finance & $(2.34)$ & $(0.94)$ & $(2.34)$ & $(2.07)$ \\
\hline ****** *: Significant at $1 \%, 5 \%$, and $10 \%$ level, respectively. t-statistics & in parentheses. &
\end{tabular}

\subsection{Omitted Initial Income Level}

It is often suggested that it is difficult to disentangle the effects of fiscal variables from the effects of the initial income level on growth due to their high correlation (Easterly and Rebelo 1993). As a result, the significance of the fiscal variables is sensitive to the inclusion/exclusion of the initial GDP in the growth regression. In Table 6 we report the result of the baseline regression after excluding the initial GDP from the set of regressors. Again, the 
results with omitted initial GDP are comparable to the baseline results in Table 2, suggesting that the validity of our previously obtained results is not conditional on the inclusion/exclusion of the initial income level.

\begin{tabular}{lcc}
\multicolumn{3}{l}{ Table 6. Regression results that exclude the level of initial income } \\
\hline Dependent variable: GDP p.c. growth; Seigniorage: Seigniorage 1 \\
\hline Country Set & Developed & Developing \\
\hline Investment & $0.131^{* * *}$ & $0.168^{* * *}$ \\
& $(3.36)$ & $(5.17)$ \\
Population growth & $-0.634^{* *}$ & $-0.612^{* *}$ \\
& $(2.24)$ & $(2.13)$ \\
Government expenditures & $\mathbf{- 0 . 0 4 0}$ & $\mathbf{- 0 . 1 8 7 * * *}$ \\
& $\mathbf{( 0 . 4 9 )}$ & $\mathbf{( 2 . 8 1 )}$ \\
Government revenues & $\mathbf{- 0 . 0 8 6}$ & $\mathbf{0 . 1 0 3}$ \\
& $\mathbf{( 1 . 0 3 )}$ & $(\mathbf{1 . 3 6 )}$ \\
Rest of budget financing & -0.049 & $0.148^{* *}$ \\
& $(0.64)$ & $(2.43)$ \\
Initial secondary schooling & 0.002 & 0.002 \\
& $(0.26)$ & $(0.23)$ \\
Trade & $0.037^{* * *}$ & 0.002 \\
& $(4.53)$ & $(0.64)$ \\
Terms of trade growth & 0.134 & 0.113 \\
& $(1.42)$ & $(1.57)$ \\
R-square & 0.3544 & 0.2763 \\
No. of observations & 119 & 200 \\
F-test & $16.85^{* * *}$ & $11.24^{* * *}$ \\
Hausman specification test & 7.24 & $21.42^{* * *}$ \\
Confidence interval at $95 \%$ & $(-0.177,-0.076)$ & $(-0.126,-0.043)$ \\
Estimated effect of tax finance & $-0.123^{* * *}$ & $-0.081^{* * *}$ \\
& $(4.03)$ & $(3.11)$ \\
\hline ***,**, *: Significant at $1 \%, 5 \%$, and $10 \%$ level, respectively. t-statistics in parentheses
\end{tabular}

\subsection{Testing for Endogeneity}

An important econometric issue that arises in estimating our empirical model is that several of our controls - in particular investment, trade, and the fiscal variables - are potentially endogenous. To address such problem, Arellano and Bond (1991) propose a GMM panelestimator that employs an increasing sequence of lagged values of the levels of all endogenous and predetermined variables as instruments. The consistency of the Arellano-Bond estimator depends crucially on the assumption that the errors are not serially correlated. However, since the removal of country-specific effects through first-differencing induces first-order serial correlation in the transformed errors, the appropriate null hypothesis is that second-order serial correlation is absent from the transformed residuals. In addition, Arellano and Bond (1991) 
suggest a Sargan test for over-identifying restrictions, which tests for the overall validity of the instruments.

Table 7. Regression results that account for endogeneity

\begin{tabular}{|c|c|c|c|c|}
\hline \multicolumn{5}{|c|}{ Dependent variable: GDP p.c. growth; Seigniorage: Seigniorage1 } \\
\hline \multirow[b]{2}{*}{ Country Set } & \multicolumn{2}{|c|}{ Static Model } & \multicolumn{2}{|c|}{ Dynamic Model } \\
\hline & Developed $^{1}$ & Developing $^{2}$ & Developed $^{1}$ & Developing $^{2}$ \\
\hline Log of initial p.c. GDP & $\begin{array}{l}0.002 \\
(0.16)\end{array}$ & $\begin{array}{l}-0.062 * * * \\
(2.65)\end{array}$ & 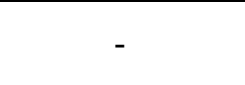 & 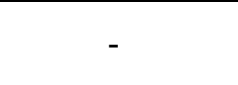 \\
\hline Investment & $\begin{array}{l}0.213 * * * \\
(3.01)\end{array}$ & $\begin{array}{l}-0.037 \\
(0.34)\end{array}$ & $\begin{array}{l}0.072 \\
(0.98)\end{array}$ & $\begin{array}{l}-0.070 \\
(0.41)\end{array}$ \\
\hline Population growth & $\begin{array}{c}-1.162 * * \\
(2.16)\end{array}$ & $\begin{array}{l}-1.178 \\
(1.37)\end{array}$ & $\begin{array}{l}-0.275 \\
(0.48)\end{array}$ & $\begin{array}{l}-0.760 \\
(0.76)\end{array}$ \\
\hline Government expenditures & $\begin{array}{l}-0.067 \\
(0.43)\end{array}$ & $\begin{array}{c}-0.318 * * * \\
(2.87)\end{array}$ & $\begin{array}{l}-0.226 \\
(1.19)\end{array}$ & $\begin{array}{c}-0.297 * * \\
(1.98)\end{array}$ \\
\hline Government revenues & $\begin{array}{l}0.012 \\
(0.57)\end{array}$ & $\begin{array}{l}0.345 * * \\
(1.96)\end{array}$ & $\begin{array}{l}0.016 \\
(0.07)\end{array}$ & $\begin{array}{c}0.323 * * \\
(1.86)\end{array}$ \\
\hline Rest of budget financing & $\begin{array}{l}-0.133 \\
(1.30)\end{array}$ & $\begin{array}{l}0.055 \\
(0.56)\end{array}$ & $\begin{array}{l}-0.074 \\
(0.44)\end{array}$ & $\begin{array}{l}0.072 \\
(0.62)\end{array}$ \\
\hline Initial secondary schooling & $\begin{array}{c}0.022^{*} \\
(1.91)\end{array}$ & $\begin{array}{r}-0.001 \\
(0.03)\end{array}$ & $\begin{array}{l}0.008 \\
(0.96)\end{array}$ & $\begin{array}{l}-0.096^{*} \\
(1.71)\end{array}$ \\
\hline Trade & $\begin{array}{l}0.037 \\
(1.21)\end{array}$ & $\begin{array}{l}0.034 \\
(1.02)\end{array}$ & $\begin{array}{l}-0.013 \\
(0.39)\end{array}$ & $\begin{array}{c}0.092 * * * \\
(2.58)\end{array}$ \\
\hline Terms of trade growth & $\begin{array}{c}0.425^{* *} \\
(2.34)\end{array}$ & $\begin{array}{l}0.026 \\
(0.23)\end{array}$ & $\begin{array}{l}0.410 * * * \\
(2.85)\end{array}$ & $\begin{array}{l}0.023 \\
(0.21)\end{array}$ \\
\hline Lagged growth & - & - & $\begin{array}{l}-0.538 * * * \\
\quad(5.46)\end{array}$ & $\begin{array}{l}-0.059 \\
(0.47)\end{array}$ \\
\hline No. of observations & 81 & 119 & 81 & 119 \\
\hline Sargan test ${ }^{3,5}[\mathrm{p}$-value $]$ & $\begin{array}{c}15.75 \\
{[0.610]}\end{array}$ & $\begin{array}{c}19.08 \\
{[0.387]}\end{array}$ & $\begin{array}{c}15.32 \\
{[0.639]}\end{array}$ & $\begin{array}{c}22.59 \\
{[0.207]}\end{array}$ \\
\hline $\begin{array}{l}\text { Second order serial } \\
\text { correlation test }^{4}[p \text {-value }]\end{array}$ & $\begin{array}{c}1.468 \\
{[0.142]}\end{array}$ & $\begin{array}{l}-0.199 \\
{[0.842]}\end{array}$ & $\begin{array}{c}0.441 \\
{[0.660]}\end{array}$ & $\begin{array}{l}-0.503 \\
{[0.615]}\end{array}$ \\
\hline Confidence interval at $95 \%$ & $(-0.208,0.098)$ & $(-0.093,0.147)$ & $(-0.342,-0.077)$ & $(-0.277,0.330)$ \\
\hline $\begin{array}{l}\text { Estimated effect of tax } \\
\text { finance }\end{array}$ & $\begin{array}{r}-0.051 \\
(0.70)\end{array}$ & $\begin{array}{l}0.121 \\
(0.78)\end{array}$ & $\begin{array}{c}-0.234 * * * \\
(3.45)\end{array}$ & $\begin{array}{l}0.029 \\
(0.15)\end{array}$ \\
\hline $\begin{array}{l}\text { ***,**,*: Significant at } 1 \% \text {, } \\
{ }^{1} \text { Germany drops form the co } \\
2 \text { Ethiopia, Romania, and S. } \\
3 \text { The null hypothesis is that } \\
{ }^{4} \text { The null hypothesis is that } t \\
5 \text { The reported statistic is fror }\end{array}$ & $\begin{array}{l}\text { and } 10 \% \text { level, } \\
\text { set due to the la } \\
\text { drop from the c } \\
\text { struments used a } \\
\text { rors in the first-c } \\
\text { two-step estima }\end{array}$ & $\begin{array}{l}\text { ctively. Robus } \\
\text { f sufficient dat } \\
\text { ry set due to tl } \\
\text { t correlated w } \\
\text { ence regressio }\end{array}$ & $\begin{array}{l}\text { tatistics in parentl } \\
\text { ints. } \\
\text { ck of sufficient di } \\
\text { he residuals. } \\
\text { hibit no second-o }\end{array}$ & $\begin{array}{l}\text { es. } \\
\text { points. } \\
\text { r serial correlat }\end{array}$ \\
\hline
\end{tabular}

While Arellano and Bond (1991) are primarily interested in dynamic panels, their estimator can be applied just as well when estimating static models. Since our earlier modelspecifications are static, we begin by re-estimating our model for both developed- and developing-country samples using the Arellano-Bond procedure. As instruments we use the second lag of the levels of investment, trade, and the fiscal variables and the first lag of initial 
income, which we treat as predetermined; all other variables are assumed to be exogenous and instrument for themselves. ${ }^{13}$

The results for the static model are reported in the first two columns of Table 7. Although the results remain robust in the case of developing countries, the same does not appear to be true for the set of developed countries. This static specification, however, may not be appropriate for the sample of developed countries. While the Sargan test of over-identifying restrictions does not reject the null that our instruments are uncorrelated with the residuals for both the developedand developing-country samples, we only marginally fail to reject the null hypothesis of no second-order serial correlation for the developed-country sample at the 10 percent level.

This marginal non-rejection of the null of serial correlation is worrisome, suggesting a possible misspecification of our model. In addition, Bleaney et al. (2001) finds substantial lagged effects of growth for a similar set of OECD countries, suggesting that the long-run effects of fiscal policy take more than one interval (five years) to be effective. Following their approach, we introduce lagged growth as an explanatory variable for both sets of countries. ${ }^{14}$ Introduction of a lagged dependent variable indicates that the assumption of no serial correlation in the errors cannot be rejected for both samples (Columns 3 and 4 of Table 7). Moreover the Sargan test statistic also strongly supports the validity of our instruments. The results from the dynamic specifications suggest that our original results are robust and are not due to simultaneity bias or omitted variables (although now appear to be greater in magnitude). Finally, note that, while lagged growth appears significant for the high-income sample as predicted by Bleaney et al. (2001), the results for the developing countries are not affected by the introduction of this dynamic element.

\section{Conclusions}

It is widely believed among economists and development experts that economic policies should be made conditional upon the stages of economic development due to the vast differences

\footnotetext{
${ }^{13}$ In sensitivity analyses, we also considered the possibility that the initial income variable is endogenous (Barro and Sala-i-Martin 1995). We did the same for the schooling variable in light of recent evidence of reverse causation from schooling to growth (Bils and Klenow 2000). Using the second lagged levels as their instruments, our results did not change.

${ }^{14}$ To capture the effect of lagged growth and to be consistent with Bleaney et al.'s (2001) approach, we exclude initial income level from our estimated regression. As instruments of lagged growth, we use its second lagged level.
} 
in the functioning and the structure of developed and developing economies. Despite this, most of the analyses about the growth effects of public spending conducted at the theoretical and at the empirical levels have ignored the task of linking the findings and policy prescriptions to the stages of economic development. In this study, we pay special attention to this omission. Here, our interest is not to identify the prevalent mode of financing across the countries. Rather, our contribution lies in identifying the best way to finance public expenditures in the two sets of countries. At the theoretical level, the analysis suggests that, for the high-income economies, an expansion in government expenditures financed with taxes retards growth more than if it were financed through seigniorage. However, an opposite result is obtained in the case of low-income countries. The empirical analysis based on a panel data set of 21 OECD countries and 40 developing countries over the period 1972-1999 provides strong support for our results.

\section{Appendix A}

Proof of Proposition 1. First, note from equation (9) that

$$
\begin{aligned}
& \frac{\partial \Phi}{\partial R^{m}}=\frac{\gamma}{1+\gamma} \frac{\Phi}{R^{m}}>0, \\
& \frac{\partial \Phi}{\partial \rho}=-\frac{\gamma}{1+\gamma} \frac{\Phi}{\rho}<0 .
\end{aligned}
$$

Totally differentiating the growth rate of the economy equation (12) and the government's budget constraint equation (15), we arrange the system of equations in the following matrix form:

$$
\left[\begin{array}{ll}
a_{11} & a_{12} \\
a_{21} & a_{22}
\end{array}\right]\left[\begin{array}{c}
d \theta \\
d R^{m}
\end{array}\right]=\left[\begin{array}{ll}
a_{13} & a_{14} \\
a_{23} & a_{24}
\end{array}\right]\left[\begin{array}{l}
d \beta \\
d \tau
\end{array}\right]
$$

where

$$
\begin{aligned}
& a_{11}=1, a_{12}=-\frac{(1-\tau)(1-\alpha) A x}{(1+\Phi)^{2}} \frac{\partial \Phi}{\partial R^{m}}<0, a_{13}=0, a_{14}=-\frac{(1-\alpha) A x \Phi}{1+\Phi}<0 \\
& a_{21}=\frac{1}{A x \Phi(1+\kappa)}, a_{22}=-\left[\frac{1}{A x \Phi(1+\kappa)}+\frac{\theta-R^{m}}{A x \Phi^{2}(1+\kappa)} \frac{\partial \Phi}{\partial R^{m}}\right]<0, a_{23}=1, a_{24}=-(1-\alpha)<0 .
\end{aligned}
$$

Define $\Delta \equiv a_{11} a_{22}-a_{21} a_{12}$ to be the determinant of the left matrix on the left-hand-side of the above system. When simplified, it is found to be 


$$
\Delta=-\frac{1}{A x \Phi(1+\kappa)}-\frac{\gamma}{1+\gamma} \frac{1}{R^{m}} \frac{1}{1+\kappa}\left[\frac{\theta \Phi-R^{m}(1+\Phi)}{A x \Phi(1+\Phi)}\right]<0 .
$$

Using Cramer's rule, we obtain the effect on growth of an expansion in government spending financed via seigniorage when we impose the restriction $d \tau=0$. This implies:

$$
\left.\frac{\partial \theta}{\partial \beta}\right|_{S}=\frac{(1-\tau)(1-\alpha) A x}{(1+\Phi)^{2} \Delta} \frac{\partial \Phi}{\partial R^{m}}<0 .
$$

To obtain the effect of an expansion in government spending financed via income taxation, we set the restriction $d \beta=(1-\alpha) d \tau$. As a result:

$$
\left.\frac{\partial \theta}{\partial \beta}\right|_{T}=\left(1+\frac{R^{m}}{\gamma \theta}\right) \frac{1}{1+\kappa} \frac{(1-\tau)(1-\alpha) A x}{(1+\Phi)^{2} \Delta} \frac{\partial \Phi}{\partial R^{m}}<0 .
$$

Table A1. Numerical Simulation Parameters

\begin{tabular}{|c|c|c|c|c|c|c|c|c|c|c|}
\hline & \multicolumn{4}{|c|}{ Author's parameters } & \multicolumn{6}{c|}{ Our parameters } \\
\hline Authors & $\boldsymbol{\gamma}$ & $\boldsymbol{\tau}$ & $\boldsymbol{A}$ & $\boldsymbol{A}$ & $\boldsymbol{\lambda}$ & $\boldsymbol{x}$ & $\boldsymbol{\pi}$ & $\boldsymbol{\kappa}$ & $\boldsymbol{R}^{\boldsymbol{m}}$ & $\boldsymbol{\delta}$ \\
\hline $\begin{array}{c}\text { King and Rebelo } \\
\text { (1990) }\end{array}$ & 9 & 0.3 & 1 & 0.33 & {$[0,1]$} & 2 & 0.5 & 0.4 & $\begin{array}{c}0.9 \\
1.1\end{array}$ & $\begin{array}{c}{[2.4, \infty]} \\
{[2.1, \infty]}\end{array}$ \\
\hline $\begin{array}{c}\text { Chari, Christiano, and } \\
\text { Kehoe (1991) }\end{array}$ & 8 & 0.26 & 1 & 0.34 & {$[0,1]$} & 2 & 0.4 & 0.3 & $\begin{array}{c}0.9 \\
1.1\end{array}$ & $\begin{array}{c}{[2.1, \infty]} \\
{[1.8, \infty]}\end{array}$ \\
\hline $\begin{array}{c}\text { Jones, Manuelli, and } \\
\text { Rossi (1993) }\end{array}$ & 1.5 & 0.22 & 1.8 & 0.36 & {$[0,1]$} & 2 & 0.2 & 0.6 & $\begin{array}{c}0.9 \\
1.1\end{array}$ & $\begin{array}{c}{[2.6, \infty]} \\
{[1.3, \infty]}\end{array}$ \\
\hline
\end{tabular}

Country Sets

\section{Appendix B}

\section{Country Sets, Data Sources, and Variables Description}

Developed OECD Countries (21): Australia, Austria, Belgium, Canada, Denmark, Finland, France, Germany, Greece, Iceland, Ireland, Italy, Luxembourg, the Netherlands, Norway, Portugal, Spain, Sweden, Switzerland, the United Kingdom, the United States.

Developing Countries (40): Argentina, Bolivia, Brazil, Burkina Faso, Burundi, Cameroon, Chile, Colombia, Costa Rica, Dominican Republic, Egypt, Ethiopia, Gambia, Hungary, India, Indonesia, Iran, Korea Republic, Lesotho, Malaysia, Mauritius, Mexico, Morocco, Nepal, Nicaragua, Pakistan, Paraguay, Peru, Romania, Senegal, Singapore, South Africa, Sri Lanka, Syrian Arab Republic, Thailand, Tunisia, Uruguay, Venezuela, Zambia, Zimbabwe. 


\section{$\underline{\text { Data Sources and Variables Description }}$}

International Monetary Fund, Government Finance Statistics (GFS)

\begin{tabular}{ll}
\hline Variables & Description \\
\hline Government revenues & Total government revenues and grants \\
Government expenditures & Total government expenditures \\
Distortionary tax revenues* & Sum of taxation on income, profits, and capital gains, taxation on social \\
& security contributions, taxation on payroll or workforce, and taxation on \\
& property \\
Non-distortionary tax revenues* & Taxation on domestic goods and services \\
Other revenues* & Sum of taxation on international trade and transactions, non-tax \\
& revenues, other tax revenues, and grants \\
Income tax revenues* & Taxation on income, profits, and capital gains \\
Other distortionary tax revenues* & Distortionary tax revenues less taxation on income, profits, and capital \\
& gains \\
\hline
\end{tabular}

Note: The classification of the variables with the asterisk follows Kneller et al. (1999) and Bleaney et al. (2001). The data are consolidated and cover all levels of government.

International Monetary Fund, International Financial Statistics (IFS)

\begin{tabular}{ll}
\hline Variables & Description \\
$\begin{array}{l}\text { Monetary base } \\
\text { Seigniorage1(base regression) } \\
\text { Seigniorage2 }\end{array}$ & Reserve money (line 14 in IFS) \\
Seigniorage3 & $\begin{array}{l}\text { Ratio of the change in high-powered money to nominal GDP (Fischer 1982) } \\
\text { Ratio of the product of the high-powered money growth rate times the level } \\
\text { of high-powered money to nominal GDP (Chamley 1991, Honohan 1996) }\end{array}$ \\
& $\begin{array}{l}\text { Ratio of high-powered money to nominal GDP in current period minus ratio } \\
\text { of high-powered money to nominal GDP in last period plus the product of } \\
\text { the ratio of high-powered money to nominal GDP in last period times the } \\
\text { growth rate of nominal GDP in current period to one plus the growth rate of }\end{array}$ \\
& $\begin{array}{l}\text { GDP in current period (Walsh 1998) } \\
\text { Ratio of the product of the inflation rate times high-powered money to the } \\
\text { product of one plus the inflation rate times nominal GDP (de Haan et al. } \\
\text { 1993, Walsh 1998) }\end{array}$ \\
\hline
\end{tabular}

World Bank, World Development Indicators (WDI) CD-ROM

\begin{tabular}{|c|c|}
\hline Variables & Description \\
\hline GDP p.c. growth rate & $\begin{array}{l}\text { Annual percentage growth rate of GDP per capita based on constant local } \\
\text { currency }\end{array}$ \\
\hline Initial p.c. GDP & Figures are in constant 1995 US dollars \\
\hline Investment & Gross capital formation ( $\%$ of GDP) \\
\hline Population growth rate & Annual population growth rate \\
\hline Budget surplus & Overall budget balance for central government ( $\%$ of GDP) \\
\hline Rest of budget financing & Overall budget balance less seigniorage measure \\
\hline Initial secondary schooling & Initial secondary school enrolment ( $\%$ gross) \\
\hline Trade & Sum of exports and imports of goods and services ( $\%$ of GDP) \\
\hline Terms of trade growth rate & $\begin{array}{l}\text { The log difference between terms of trade figures (goods and services, } \\
1995=100 \text { ) }\end{array}$ \\
\hline Inflation rate & Consumer prices (annual \%) \\
\hline
\end{tabular}


Table B1. Descriptive Statistics of Variables used in the Sensitivity Analysis

\begin{tabular}{lcccc}
\hline Variable & \multicolumn{2}{c}{ Mean } & \multicolumn{2}{c}{ Standard Deviation } \\
\multicolumn{1}{c}{ Country Set } & Developed & Developing & Developed & Developing \\
\hline Distortionary tax revenues & 0.1912 & 0.0695 & 0.0624 & 0.0422 \\
Income taxation revenues & 0.0949 & 0.0476 & 0.0387 & 0.0329 \\
Other distortionary tax revenues & 0.0963 & 0.0219 & 0.0237 & 0.0093 \\
Non-distortionary tax revenues & 0.0944 & 0.0563 & 0.0379 & 0.0279 \\
Other revenues and grants & 0.0429 & 0.0968 & 0.0167 & 0.0593 \\
Seigniorage2 & 0.0050 & 0.0163 & 0.0049 & 0.0168 \\
Seigniorage3 & 0.0024 & 0.0113 & 0.0046 & 0.0097 \\
Seigniorage4 & 0.0071 & 0.0209 & 0.0082 & 0.0176 \\
\hline
\end{tabular}

Note: Descriptive statistics for the variables as in Table 1.

\section{References}

Arellano, M., and Bond, 1991, "Some Specification Tests for Panel Data: Monte Carlo Evidence and an Application to Employment Equations", Review of Economic Statistics, 58, 277-298.

Barro, R.J., 1991, "Economic Growth in a Cross Section of Countries", Quarterly Journal of Economics, 407-444.

Barro, R., and Sala-i-Martin, X., 1995, Economic Growth, McGraw-Hill, New York.

Bhattacharya, J., Guzman, M., Huybens, E., and Smith, B.D., 1997, "Monetary, Fiscal, and Reserve

Requirement Policy in a Simple Monetary Growth Model”, International Economic Review, 38 (2), 321-350.

Bils, M and Klenow, P.J., 2000, “Does Schooling Cause Growth?”, American Economic Review, 90 (5), 1160-1183.

Bleaney, M.F., Gemmell, N., and Kneller, R., 2001, "Testing the Endogenous Growth Model: Public Expenditure, Taxation, and Growth over the Long Run", Canadian Journal of Economics, 34 (1), 3657.

Blomstrom, M., Lipsey, R.A., and Zejan, M., 1994, "Host Country Competition and Technology Transfer by Multinationals", Weltwirtschaftliches Archiv, 130, 521-533.

Brechling, F., 1973, "Wage Inflation and the Structure of Regional Unemployment”, Journal of Money, Credit, and Banking, 5, 355-384.

Cashin, P., 1995, “Government Spending, Taxes, and Economic Growth”, IMF Staff Papers, 42 (2), 237269.

Chamley, C., 1991, “Taxation of Financial Assets in Developing Countries”, World Bank Economic Review, 5, 513-534. 
Chari, V.V., Christiano, L.J., and Kehoe, P.J., 1991, “Optimal Fiscal and Monetary Policy”, Journal of Money, Credit, and Banking, 23, 519-539.

Chuang, Y., and Lin, C., 1999, "Foreign Direct Investment, R\&D and Spillover Efficiency: Evidence from Taiwan's Manufacturing Firms", Journal of Development Studies, 35, 117-137.

De Gregorio, J., 1993, "Inflation, Taxation, and Long-Run Growth", Journal of Monetary Economics, 31, 271-298.

de Haan, J., Zelhorst, D., and Roukens, O., 1993, "Seigniorage in Developing Countries", Applied Financial Economics, 3, 307-314.

Diamond, D., and Dybvig, P., 1983, "Bank Runs, Deposit Insurance and Liquidity", Journal of Political Economy, 85, 191-206.

Drazen, A., 1985, “A General Measure of Inflation Tax Revenues”, Economics Letters, 17, 327-330.

Drewes, T., 1987, "Regional Wage Spillover in Canada", Review of Economics and Statistics, 69, 224231.

Eckstein, O., and Wilson, T., 1962, “Determination of Money Wages in American Industry”, Quarterly Journal of Economics, 76, 379-414.

Espinosa-Vega, M.A., and Yip, C.K., 1999, "Fiscal and Monetary Policy Interactions in an Endogenous Growth Model with Financial Intermediaries", International Economic Review, 40 (3), 595-615.

Espinosa-Vega, M.A., and Yip, C.K., 2000, “Government Financing in an Endogenous Growth Model with Financial Intermediaries", Federal Reserve Bank of Atlanta Working Paper 2000-17.

Fischer, S., 1982, "Seigniorage and the Case for a National Money", Journal of Political Economy, 90 (2), 295-313.

Gertler, M., and Rogoff, K., 1989, "Developing Country Borrowing and Domestic Wealth", NBER Working Paper, No. 2887.

Gupta, S., Clements, B., Baldacci, E., and Mulas-Granados, C., 2005, "Fiscal Policy, Expenditure Composition, and Growth in Low-Income Countries", Journal of International Money and Finance, 24, $441-463$

Honohan, P., 1996, "Does it Matter How Seigniorage is Measured?", Applied Financial Economics, 6, 293-300.

Jones, L.E., and Manuelli, R., and Rossi, P.E., 1993, "Optimal Taxation in Models of Endogenous Growth", Journal of Political Economy, 101, 485-517.

Jovanovic, B., and Nyarko, Y., 1996, "Stepping Stone Mobility”, NBER Working Paper, No. 5651.

King, R., and Rebelo, S., 1990, "Public Policy and Economic Growth: Developing Neoclassical Implications", Journal of Political Economy, 98 (1), S126-S151. 
Klein, M, and Neumann, M.J.M., 1990, “Seigniorage: What Is It and Who Gets It?”, Weltwirtschaftliches Archiv, 126, 205-221.

Kneller, R., Bleaney, M.F., and Gemmell, N., 1999, "Fiscal Policy and Growth: Evidence from OECD Countries", Journal of Public Economics, 74, 171-190.

Levine, R., and Renelt, D., 1992, "A Sensitivity Analysis of Cross-Country Growth Regressions", American Economic Review, 82 (4), 942-963.

Mankiw, N.G., Romer, D., and Weil, D.N., 1992, "A Contribution to the Empirics of Economic Growth", Quarterly Journal of Economics, 107 (2), 407-437.

Mendoza, E.G., Milesi-Feretti, G., and Asea, P., 1997, “On the Ineffectiveness of Tax Policy in Altering Long-Run Growth: Harberger's Superneutrality Conjecture”, Journal of Public Economics, 66, 99-126.

Miller, S.M., and Russek, F.S., 1997, "Fiscal Structures and Economic Growth: International Evidence", Economic Inquiry, 35, 603-613.

Palivos, T., and Yip, C.K., 1995, "Government Expenditure Financing in an Endogenous Growth Model: A Comparison", Journal of Money, Credit, and Banking, 27, 1159-1178.

Pecorino, P., 1997, “The Optimal Rate of Inflation When Capital is Taxed”, Journal of Macroeconomics, $19(4), 657-673$.

Piazolo, M., 1996, “Determinants of Indonesian Economic Growth”, Seoul Journal of Economics, 9, 269298.

Rodriguez, C.A., 1994, “Argentina: Fiscal Disequilibria Leading to Hyperinflation”, in: Easterly, W., Rodriguez, C.A., and Schmidt-Hebbel, K. (Eds.), Public Sector Deficits and Macroeconomic Performance, Oxford University Press, 101-166.

Schreft, S., and Smith, B.D., 1997, "Money, Banking, and Capital Formation", Journal of Economic Theory, 157-182.

Shell, K., 1966, "Towards a Theory of Incentive Activity and Capital Accumulation", American Economic Review, 56, 62-68.

Thomas, R.L., and Stoney, P.J., 1971, "Unemployment Dispersion as a Determinant of Wage Inflation in the UK: 1925-66", Manchester School of Economics and Social Studies, 39, 83-116.

Van Meijl, H., 1997, "Measuring Intersectoral Spillovers", Economic Systems Research, 9, 25-46.

Walsh, C.E., 1998, Monetary Theory and Policy, MIT Press: Cambridge, Massachusetts.

Wooldridge, J.M., 2002, Econometric Analysis of Cross Section and Panel Data, MIT Press: Cambridge, Massachusetts. 